\title{
Comparison of growth and heterosis of body parameters of two varieties of snail [Archachatina marginata (Swainson1821)] and their crosses reared under tropical conditions
}

\author{
Okon, B. ${ }^{1 *}$, Ibom, L. A. ${ }^{1}$, Sam, I. M. ${ }^{2}$ and Ibiang, N. $0 .{ }^{1}$ \\ ${ }^{1}$ Department of Animal Science, University of Calabar, Calabar, Nigeria. \\ 2Department of Animal Science, Akwa Ibom State University, Obio Akpa, Oruk Anam, Nigeria. \\ “Corresponding Author. Email: profbasseyokon@gmail.com
}

Copyright (@ 2016 Okon et al. This article remains permanently open access under the terms of the Creative Commons Attribution License 4.0, which permits unrestricted use, distribution, and reproduction in any medium, provided the original work is properly cited.

Received 24th October, 2016; Accepted 7th December, 2016

\begin{abstract}
The main objective of this paper was to compare growth traits and heterosis of body parameters of two varieties of Archachatina marginata (var. ovum and var. saturalis) and their crosses under experimental conditions. Three hundred (300) juvenile snails (Archachatina marginata), one hundred (100) each of $A$. marginata var. ovum, A. marginata var. saturalis and their crosses with mean body weights of $12.40 \pm 0.58 \mathrm{~g}$ were used for the study. The snails were randomly allotted using completely randomized design into three (3) treatment varieties. Results from the study showed significant variety effect $(\mathrm{P}<0.05)$ on final body weight and average weight gain. The crossbred variety recorded the highest average weight gain compared to the other two varieties. No significant $(P>0.05)$ variety effect was observed on daily weight gain, total feed intake, daily feed intake and feed conversion ratio. The crossbred variety recorded the highest final body weight and final shell width, indicating heterotic effects on these two bodies and shell parameters. Significant variety effects $(P<0.05)$ were observed on body weight, shell length and shell "mouth" length. The low heterotic values obtained for body weight and the shell parameters supported the assertion that growth traits have low heterotic values which may be due to their high heritability. Though, low and positive heterotic values were obtained for all parameters studied, the crossbred variety recorded the highest heterotic values, which indicated that it may have heterotic advantage over the purebred varieties.
\end{abstract}

Keywords: Growth, heterosis, snail, trait, variety.

\section{INTRODUCTION}

Breed types, according to Okon et al. (2012a), have a marked effect on performance and production of snails than all other factors considered. Thus, these authors asserted that the performance of any animal is dependent upon the inherent genetic make-up and the environment in which it is raised. In Nigeria, there are different breeds of giant African land snails and they vary in size, colour, adaptability and performance (Amusan and Omidiji, 1998; Okon et al., 2012b). These breeds include Archachatina marginata, Achatina achatina, Achatina fulica, Limicolaria species and Thapsia species. Within a snail breed, there exist varietal differences in foot pigment, length of whorls, aperture size (length and width) and egg clutch size (Okon and Ibom, 2012). Archachatina marginata is the largest known breed of snail in Africa (Omole, 1998; Olawoyin and Ogogo, 2006; Okon et al., 2012b) and has two varieties namely, Archachatina marginata var. ovum and Archachatina marginata var. saturalis. On Archachatina marginata var. ovum, both columella and parietal callus are white, while on Archachatina marginata var. saturalis, both columella and parietal callus are red. Most studies carried out combined these two varieties as one breed and these have not really given the true performance or production of these varieties. 
Growth studies of $A$. marginata var. ovum and $A$. marginata var. saturalis have been extensively done by Ibom et al. (2011), Ibom and Okon (2012), Okon et al. (2008, 2012a, 2012b, 2014), Imran and Alarape (2012), Isah and Peter (2012), Jayeola et al. (2013), Onuoha (2014), Oyeagu et al. (2015), Fayenuwo et al. (2015), Egbu et al. (2015), and Ejidike and Oladipo (2015). Growth measured in terms of body weight gain (BWG) is the most widely used growth index from birth to maturity (Okon and Ibom, 2012). In snails, the weight at hatch is the first indicator of hatchling growth rate and is useful as a starting point for measuring subsequent growth. Okon and Ibom (2012) also pointed out that the growth rate of snails can be measured as the increase in shell size, this being the obvious phenotypic trait. Similarly, Akinnusi $(2002,2004)$ opined that snail growth is measured by shell size.

Growth rate values in snails under the tropical condition have been reported by many authors (Ayayi et al., 1978; Hodasi, 1984; Udedibie et al., 1986; Oyelade et al., 2013; Okon et al., 2013). The growth rate of snail varies considerably between individuals in each population group, thus Cobbinah (1993) opined that snails show differences in growth rates. Ibom (2009) stated that dimensional shell parameters (shell length, shell width and shell thickness) and aperture (shell "mouth") parameters are indices that can be taken at hatch and used to measure subsequent snail growth. Body weight and body components are the growth parameters used to measure growth in animals and are common measures of size and growth rate.

Heterosis refers to the mean performance of hybrid progeny relative to the mid-parent value (Ibe, 1998). The author added that if the average performance of the hybrid is better than the mid-parent value, heterosis is positive, otherwise it is negative. Positive heterosis is referred to as hybrid vigour. Heterosis, according to Crow (2008) is predicted to be high in small population with gene flow and to increase with population structure, whereas it is reduced by inbreeding. Also, Asumoah (1999) reported that stressful environment may influence the expression of heterosis and hybrid performance may be reduced by out breeding depression. Although, heterosis in these snail varieties does not result from fixation load, its experimental estimation provides relevant information on the trends of heterosis on them, but heterosis is expected to be mainly contributed by mildly deleterious alleles (Clift, 2010) and maximized for moderate to intermediate selection coefficients (Crow, 2008).

Growth traits show moderate heterosis. However, heterosis is not very important for conformation (or body dimension) and composition traits which have high heritabilities and show little or no depression from inbreeding (lbe, 1998). Integrating snails into target gene pool in an organized breeding project according to Clift (2010) will be beneficial as farmers had used hybrid vigour or heterosis to enhance growth and reproductive performance of farm animals (e.g., cattle, sheep, poultry and pigs).

This paper compared growth traits and heterosis of body and shell parameters of two varieties of Archachatina marginata (var. ovum and var. saturalis) and their crosses under experimental conditions.

\section{MATERIALS AND METHODS}

\section{Experimental site}

The study was carried out at the Botanical Garden of University of Calabar, Calabar, Nigeria. Calabar (Longitude $8^{\circ} 17^{\prime}$ and $10^{\circ} 43^{\prime} \mathrm{E}$; Latitude 4058' and $15^{\circ} 39^{\prime} \mathrm{N}$ ) has annual rainfall and temperature ranges between 1260 to $1280 \mathrm{~mm}$ and 25 to $30^{\circ} \mathrm{C}$ respectively (CRADP, 1992). The botanical garden where the research was carried out provided a mini-environment similar to the natural habitat of snails - with trees (e.g., Cola abure, Citrus spp., Carica papaya, Musa spp., Gmelina aborea), crops (e.g., cassava and yams) and forages like Centrosoma pubescence and Panicum maximum which provided shades that protected the hutches and snails from direct sunlight and heavy rainfall.

\section{Experimental animals}

Three hundred (300) juvenile snails, one hundred (100) each of the three varieties, Archachatina marginata var. ovum (AMO), Archachatina marginata var. saturalis (AMS) and their crosses (AMO $\times$ AMS) with mean body weights of $12.40 \pm 0.58 \mathrm{~g}$ were obtained from an earlier study in the same location for this study. The snails were randomly allotted to the three (3) treatments of the varieties studied. The snails in the three (3) treatments were managed in wooden cells compartments kept under trees shades for the 5 months of study which lasted from May to September, 2015. The cells had dimensions of $40 \mathrm{~cm}$ (length), $40 \mathrm{~cm}$ (width) and $40 \mathrm{~cm}$ (depth). Each treatment was replicated ten (10) times in a completely randomized experimental design (CRD). The juvenile snails were housed in thirty (30) cells with ten (10) snails per cell containing sterilized loamy soil moistened with water for easy management. The snails were placed on mixed-diet of forages (fresh paw-paw leaves) and concentrates (containing $24 \% \mathrm{CP}, 15 \% \mathrm{Ca}$ and $2650 \mathrm{kcal} / \mathrm{kgME}$ ). Fresh cool water was supplied ad libitum in shallow troughs during the study. The three (3) varieties of snails were kept under similar environmental and management conditions.

\section{Measurements of body and shell parameters of snails}

The body weights (BDW) were taken using Scout $\mathrm{Pro}^{\circledR}$ electronic scale with sensitivity of $0.01 \mathrm{~g}$, while dimensional shell parameters were measured using Vernier Caliper. The dimensional shell parameters were shell 
Table 1. Growth Performance Traits of Archachatina marginata varieties (var. ovum and var. saturalis) and their crosses.

\begin{tabular}{|c|c|c|c|c|}
\hline \multirow{2}{*}{\multicolumn{2}{|c|}{ Parameters }} & \multicolumn{3}{|c|}{ Varieties } \\
\hline & & $\mathrm{T}_{1}$ (AMO) & $\mathrm{T}_{2}$ (AMS) & $\begin{array}{l}\mathrm{T}_{3} \text { (AMO } \mathrm{x} \\
\text { AMS) }\end{array}$ \\
\hline Initial body weight(g) & & $12.40 \pm 0.59$ & $12.40 \pm 0.57$ & $12.40 \pm 0.58$ \\
\hline Final body weight(g) & & $20.03 \pm 0.94^{a}$ & $17.08 \pm 0.85^{b}$ & $20.02 \pm 1.01^{\mathrm{a}}$ \\
\hline Average weight gain(g & & $7.63 \pm 1.11^{\mathrm{b}}$ & $7.94 \pm 1.56^{b}$ & $8.86 \pm 0.81^{a}$ \\
\hline Daily weight gain(g) & & $0.05 \pm 0.01$ & $0.06 \pm 0.01$ & $0.06 \pm 0.01$ \\
\hline Total feed intake $(\mathrm{g})$ & & $17.02 \pm 1.68$ & $17.03 \pm 1.56$ & $17.04 \pm 1.76$ \\
\hline $\begin{array}{ll}\text { Average } & \text { Daily } \\
\text { intake }(g) & \end{array}$ & feed & $0.14 \pm 0.01$ & $0.14 \pm 0.02$ & $0.14 \pm 0.02$ \\
\hline $\begin{array}{l}\text { Feed conversion } \\
\text { (FCR) }\end{array}$ & ratio & $0.46 \pm 0.07$ & $0.42 \pm 0.04$ & $0.62 \pm 0.04$ \\
\hline
\end{tabular}

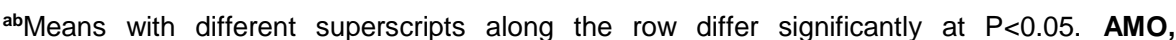
Archachatina marginata var. ovum, AMS, Archachatina marginata var. saturalis.

length (SL), shell width (SW), shell "mouth" length (SML) and shell "mouth" width (SMW). The measurements were as described in Ibom (2009) and El Zaffir et al. (2011).

\section{Data Analysis}

The fixed model used in the experiment is show below as described by lbom, 2009.

$\mathbf{Y}_{\mathrm{ij}}=\mu+\mathbf{S}_{\mathrm{i}}+\mathbf{e}_{\mathrm{ij}}$

Where: $Y_{i j}=$ Single observation, $\mu=$ Common mean, $S_{i}=$ Fixed effect of snail varieties $(i=1-3)$ and $e_{i j}=$ Random error associated with the measurement of each observation

Heterosis was estimated using the formular below (Ibe, 1998):

$\%$ Heterosis $=\frac{(\mathbf{H 1}-\mathbf{P})}{\mathbf{P}} x \frac{\mathbf{1 0 0}}{1}$

Where $\mathrm{H}_{1}=$ Average performance of offspring and $\mathrm{P}=$ Average performance of parents

Data were subjected to analysis of variance (ANOVA) for Completely Randomised Design (CRD) experiment using Statistical Analysis System (SAS, 2006). Significantly different means were separated using Duncan's New Multiple Range Test (Duncan, 1995) as outlined by Obi (2002).

\section{RESULTS AND DISCUSSION}

Growth performance traits of the three Archachatina marginata varieties (AMO, AMS and AMO $\times$ AMS) are presented in Table 1. The initial weight recorded no significant $(P>0.05)$ variety effect, while significant variety effect $(P<0.05)$ existed on final body weight $(F B W)$ and average weight gain (AWG). The AMO recorded the highest FBW, followed by AMO $x$ AMS, while AMS recorded the least value. The results of FBW obtained fell within the range mean final body weight values from 16.43 \pm 0.6 to $24.57 \pm 3.5 \mathrm{~g}$ reported by Ademolu et al. (2004) for giant African land snails (Archachatina marginata) fed different nitrogen sources, but higher than Egbu (2015) range from 12.87 to $14.89 \mathrm{~g}$ for hatchlings of Archachatina marginata (A. M.). Opara (2010) reported lower mean FBW values of $16.21 \mathrm{~g}, 14.07 \mathrm{~g}$ and $17.75 \mathrm{~g}$ for $F_{1}$-hybrids of three (3) giant African land snail ectotypes. The differences in the mean FBW values reported by the different authors might be due to the body weight, age, variety and size of the parent stock used, the feed type as well as management system adopted. The better performance observed for final body weight could be due to the combination of forage and concentrate as reported that snail's performance is better on mixed-feeding regime.

The AWG showed significant variety $(P<0.05)$ effect, confirming heterosis or hybrid vigour for this growth trait. The AWG obtained for this study is quite higher than the range of $0.08 \pm 0.02$ to $0.11 \pm 0.01 \mathrm{~g}$ reported by Egbu et al. (2015) for hatchlings of Archachatina marginata snails fed varying levels of palm kernel cake. The reason being that Egbu et al. (2015) worked with hatchlings of Archachatina species, while this study was on juveniles of the three varieties of $A$. marginata.

There were no significant $(P>0.05)$ variety effects on DWG, TFI, DFI, and FCR. The TFI consumed in this study were similar to the mean total fed intake of $17.66 \mathrm{~g}, 17.98$ $\mathrm{g}$ and $17.43 \mathrm{~g}$ reported by Omole et al. (2007) for Archachatina marginata snails raised on different stocking rates. The DFI obtained in Table 1 were similar to the mean DFI intake values of $0.14 \pm 0.16 \mathrm{~g}, 0.13 \pm 0.16 \mathrm{~g}$, $0.15 \pm 0.16 \mathrm{~g}$ and $0.18 \pm 0.16 \mathrm{~g}$ reported by Oni et al. 
Table 2. Shell Parameters of Archachatina marginata varieties (var. ovum and var. saturalis) and their crosses.

\begin{tabular}{|c|c|c|c|}
\hline \multirow{2}{*}{ Parameters } & \multicolumn{3}{|c|}{ Varieties } \\
\hline & $\mathrm{T}_{1}$ (AMO) & $\mathrm{T}_{2}$ (AMS) & $\mathrm{T}_{3}(\mathrm{AMO} \times \mathrm{AMS})$ \\
\hline Initial shell length(cm) & $3.85 \pm 0.08^{a}$ & $3.36 \pm 0.09^{b}$ & $3.82 \pm 0.08^{a}$ \\
\hline Final shell length(cm) & $4.47 \pm 0.16$ & $4.48 \pm 0.12$ & $4.60 \pm 1.11$ \\
\hline Shell length increment(cm) & $0.92 \pm 1.14^{\mathrm{b}}$ & $1.12 \pm 1.13^{a}$ & $0.88 \pm 0.09^{b}$ \\
\hline Initial shell width(cm) & $2.85 \pm 0.07^{a b}$ & $2.41 \pm 0.06^{b}$ & $2.61 \pm 0.05^{a}$ \\
\hline Final shell width(cm) & $3.45 \pm 0.08^{a}$ & $3.22 \pm 0.07^{b}$ & $3.48 \pm 0.07^{a}$ \\
\hline Shell width increment(cm) & $0.87 \pm 0.11$ & $0.81 \pm 0.09$ & $0.87 \pm 0.06$ \\
\hline Initial shell “mouth” length(cm) & $2.62 \pm 0.05^{\mathrm{a}}$ & $2.34 \pm 0.05^{b}$ & $2.59 \pm 0.04^{a}$ \\
\hline Final shell "mouth" length(cm) & $3.34 \pm 0.08$ & $3.24 \pm 0.08$ & $3.27 \pm 0.05$ \\
\hline $\begin{array}{l}\text { Shell "mouth" length } \\
\text { increment }(\mathrm{cm})\end{array}$ & $0.72 \pm 0.07$ & $0.07 \pm 0.09$ & $0.68 \pm 0.05$ \\
\hline Initial shell "mouth" width(cm) & $1.56 \pm 0.06^{\mathrm{a}}$ & $1.39 \pm 0.03^{b}$ & $1.49 \pm 0.03^{a b}$ \\
\hline Final shell "mouth" width (cm) & $2.05 \pm 0.03$ & $2.06 \pm 0.04$ & $2.03 \pm 0.05$ \\
\hline Shell "mouth" width increment(cm) & $0.49 \pm 0.06$ & $0.57 \pm 0.04$ & $0.55 \pm 0.03$ \\
\hline
\end{tabular}

abMeans within the same row with different superscripts are significantly different $(P<0.05)$. AMO, Archachatina marginata var. ovum, AMS, Archachatina marginata var. saturalis.

(2012) for A. M. snails fed vary protein and energy levels. Okonkwo et al. (2000) reported higher average DFI values of $1.41 \pm 0.07 \mathrm{~g}, 1.52 \pm 0.07 \mathrm{~g}, 1.97 \pm 0.07 \mathrm{~g}, 1.61 \pm 0.07 \mathrm{~g}$, $1.87 \pm 0.07 \mathrm{~g}$ and $1.50 \pm 0.07 \mathrm{~g}$ for $\mathrm{A}$. M. snails feed dietary levels of Moringa oleifera leaf-meal. The differences in TFI and average DFI reported by these authors could be attributed to feed types, forage materials and breed or genotype effect of $A$. M. snails used as well as the age, size, variety and weight of parental $A$. M. snails used in their studies. The FCR which is an indication of efficiency of feed utilization in the snail varied significantly across the varieties $(P>0.05)$. The results of FCR obtained in this study were quite higher than those of $0.23,0.20,0.19$, $0.24,0.32$ and 0.07 reported by Okonkwo et al. (2000) for A. M. snails fed varying dietary levels of Moringa oleifera leaf-meal. The feed was better utilized in the purebred AMS with the least FCR value, than the $A M O$ and the $A M O$ $x$ AMS.

Table 2 shows the shell parameters of $A$. marginata varieties (AMO, AMS, and AMO $x$ AMS) studied. Significant difference $(P<0.05)$ variety effects were observed in the initial shell length (SL), initial shell width (SW) and initial shell "mouth" length (SML). No significant $(P>0.05)$ variety effects were observed in final shell length, final shell "mouth" length and final shell "mouth" width, except in final shell width $(P<0.05)$. Similarly, no significant $(P>0.05)$ variety effects were observed for increment in SW, SML and SMW, except in SL $(\mathrm{P}<0.05)$.

The AMO $x$ AMS recorded the highest final $S L$ and final $S W$ than the other varieties, indicating heterotic effects on these two parameters. The final SL value of AMO x AMS in this study was similar to mean shell length of $4.62 \pm 0.08$ $\mathrm{cm}$ reported by Badmos et al. (2011) for $A$. marginata fed a mixed-diet of concentrate and forages. Ejidike (2004) reported similar shell length values of $4.70 \pm 0.30 \mathrm{~cm}$ and $5.70 \pm 0.30 \mathrm{~cm}$ for grower $A$. marginata fed different dietary protein levels, whereas Okon et al. (2012b) reported higher mean shell length values of $9.76 \mathrm{~cm}$ and $10.44 \mathrm{~cm}$ for mature $A$. marginata and $A$. fulica respectively. The differences in mean shell length values reported by these authors could be attributed to the feeding regime used, breed, ectotypes and variety of the snail, their different ages and the prevailing environmental conditions. The final shell width value of the AMO $x$ AMS in this study (Table 2) was similar to the mean shell width values of 3.50 $\pm 0.20 \mathrm{~cm}$ and $3.70 \pm 0.30 \mathrm{~cm}$ reported by Ejidike (2002) for $A$. marginata snails fed different dietary levels.

The values of heterosis for body and shell parameters of A. marginata obtained in this study are shown in Table 3 which showed that all the varieties expressed positive heterotic values for body and shell parameters studied. Significant difference $(P<0.05)$ variety effects were observed on body weight (BDW), shell length (SL) and shell "mouth" length (SML). No significant $(P>0.05)$ variety effects were observed on the shell width (SW) and shell "mouth" width (SMW). The positive heterotic values expressed by body and shell parameters were in line with Nwakpu and Omeje (2005) and lbom et al. (2014) who reported that the effects of heterosis are most often but not always positive, and depend mainly on choice of parents and selection pressure applied on parental lines (breeds).

The AMO x AMS recorded the highest heterotic values 
Table 3. Heterosis (\%) values of Body Weight, SL, SW, SML, SMW of Archachatina marginata varieties and their crosses.

\begin{tabular}{lcccc}
\hline \multirow{2}{*}{ Traits } & \multirow{2}{*}{ Age in months } & \multicolumn{3}{c}{ Varieties } \\
\cline { 3 - 5 } & & $\mathbf{T}_{\mathbf{1}}$ (AMO) & $\mathbf{T}_{\mathbf{2}}$ (AMS) & $\mathbf{T}_{\mathbf{3}}$ (AMO $\mathbf{A}$ AMS) \\
\hline Body weight & 5 & $56.36^{\mathrm{b}}$ & $58.89^{\mathrm{b}}$ & $63.59^{\mathrm{a}}$ \\
Shell Length & 5 & $20.98^{\mathrm{b}}$ & $22.97^{\mathrm{b}}$ & $34.11^{\mathrm{a}}$ \\
Shell Width & 5 & 29.21 & 27.97 & 30.22 \\
Shell “Mouth" Length & 5 & $26.90^{\mathrm{b}}$ & $27.37^{\mathrm{b}}$ & $39.74^{\mathrm{a}}$ \\
Shell "Mouth" Width & 5 & 33.99 & 34.67 & 35.28 \\
\hline
\end{tabular}

${ }^{a b}$ Means with different superscripts along the same row are significantly different $(P<0.05)$. AMO, Archachatina marginata var. ovum, AMS, Archachatina marginata var. saturalis.

than AMO and AMS varieties for all the traits and parameters studied (Table 3), showing that the crossbred variety has advantage over the two purebred varieties. The results of heterosis of body weight in this study was similar to heterosis of body weight of $53.73 \%$ and $57.75 \%$ reported by lbom et al. (2011) for purebred black skinned and purebred white skinned $A$. marginata ectotypes respectively, but lower than the heterosis of body weight of $71.71 \%$ for the crossbred $A$. marginata variety. However, the heterosis values in this study for body weight were in contrast with lbom et al. (2014) who reported lower heterosis values of $38.89 \%$ (purebred black) and $37.01 \%$ (purebred white) and $53.59 \%$ (crossbred) A. marginata for body weight at hatch. The heterotic values of shell parameters (SL, SW, SML and SMW) at five (5) months of this study were low (Table 3), as these shell parameters are known to have high heritability; supporting earlier findings of Cliff (2010) and lbom et al. (2014) that heterosis tends to be greater for traits that have low heritability (e.g., reproductive traits), and small for traits that are highly heritable (e.g., growth traits).

\section{CONCLUSION}

This study revealed that there were significant variety effects $(P<0.05)$ on FBW and $A W G$, confirming heterotic effects for these growth traits. The crossbred (AMO $x$ AMS) variety recorded the highest AWG, followed by the AMS variety, while $A M O$ variety recorded the least value. There were no significant $(P>0.05)$ variety effect on DWG, TFI, DFI and FCR. The AMO $\times$ AMS recorded the highest final SL and final SW than the other two varieties, indicating heterotic effects again on the two shell parameters. Results for all body and shell parameters studied showed low, and positive heterotic values. There were significant variety effects $(P<0.05)$ observed on BDW, SL and SML. The heterotic values obtained for body and shell parameters, though low, tend to support the assertion that growth traits have low heterotic values which may be because they are highly heritable. The crossbred variety recorded the highest heterotic values than the two purebred varieties for all the body and shell parameters studied, indicating that the crossbred variety has heterotic advantage over the purebred white variety and purebred black variety.

\section{REFERENCES}

Ademolu, K. O., Idowu, A. B., Mafina, C. F., \& Osinowo, A. O. (2004). Peformance, Proximate and Mineral Analysis of African Giant Land Snails (Archachatina margnata) fed different Nitrogen Sources. African Journal of Biotechnology, 3(8), 412-417.

Akinnusi, O. (2002). Introduction to Snails and Snail Farming. Triolas Exquisite Ventures Abeokuta, Nigeria. Pp. 5-20.

Akinnusi, O. (2004). Introduction to Snails and Snail Farming. $1^{\text {st }}$ ed. Triolas Exquisite Ventures Abeokuta, Nigeria. Pp. 28-78.

Amusan, J. A., \& Omidiji, M. O. (1998). Edible land snail. A technical guide to snail farming in the tropics. Ibadan: Variety Printed Limited. Pp. 1-60.

Asumoah, S. A. (1999). Ecology and status of the giant African land snails in the Bin biosphere reserve in Ghana Final Report. Ecological studies on the giant African land snails, Pp. 16-17.

Ayayi, S. S., Tewe, O. O., Moriarty, C., \& Awesu, M. O. (1978). Observation on the biology and nutritive value of the African giant land snail. [Archachatina marginata (Swainson)]. East African Wildlife Journal, 16, 85-95.

Badmos, A. H. A., Joseph, J. K., Belewu, M. A., \& Okukpe, K. M. (2011). Growth parameters of giant African land snails as influenced by different sources of dietary calcium in Ilorin, Nigeria. Proceedings, $36^{\text {th }}$ Conference, Nigeria Society for Animal Production, 13 - 16 March, 2011. University of Abuja, Nigeria. Pp. 318-320.

Clift, L. (2010). Hybrid vigour of heterosis in farm animals. Experiences with dairy cattle crossbreeding in New Zealand. Proceeding of the 53 $3^{\text {rd }}$ Annual meeting of the European Association for Animal Production (AMEAAP) 10 Winnipeg MB., Canada, Pp. 1-4.

Cobbinah, J. R. (1993). Snail farming in West Africa. A practical guide. U. K. Sayee Publishing. CTA publication. Pp. 5-7.

Crow, J. F. (2008). Mid-century controversies in population genetics. Annual Revolutionary Genetics. 42, 1-16.

CRADP (1992). Cross River Agricultural Development Project. Report on Wetlands of Cross River State, Nigeria. P. 115.

Duncan, D. B. (1995). New multiple range test. Biometrics, 11, 1-42.

Egbu, C. F., Okpara, M. O., Ekwu, U. S., \& Oyeagu, C. E. (2015). Growth response of Archachatina marginata hatchlings fed 
varying levels of palm kernel cake diet in the humid tropics. Proceedings, $4^{\text {th }}$ International Conference/Workshop on giant land snail, June $1^{\text {st }}-4^{\text {th }} .2015$. Pp. 166-170.

Ejidike, B. N., \& Oladipo, D. D. (2015). Effect of fluted pumpkin seed meal in the diet of African giant land snail (Archachatina marginata). Proceedings of the $4^{\text {th }}$ International Conf./Workshop on giant African land snail, Akwa, June, $1^{\text {st }}$ $4^{\text {th }}, 2015$, Pp. $112-116$.

Ejidike, B. N. (2002). Snail rearing practices in Southern Nigeria. Proceedings, 27th Annual Conference, Nigeria Society for Animal Production (NSAP), March 17 - 20th, 2002. Akure, Nigeria. Pp. 303-308.

Ejidike, B. N. (2004). Growth performance and nutrient utilization of African giant land snails (Archachatina marginata) hatchlings fed different protein diets. Food, Agriculture and Environment. 2(1), 160-162.

El Zaffir, B., El sheik, E. O., \& Zuhier, N. M. (2011). Some linear measurements of Bulinus truncates snails from water bodies of two agricultural schemes in Khartoun State, Sudan. University of African Journal of Science, 1(1), 35-43.

Fayenuwo, J. O., Adekunle, O. F., Omole, A. J., Okpeze, C. N., Ajasin, F. O., \& Ononogbu, C. O. (2015). Growth and reproduction indices of growing snails fed different proportion of leaves of Moringa oleifera and pawpaw. Proceedings of the $4^{\text {th }}$ International Conf./Workshop on giant African land snail, $1^{\text {st }}$ - $4^{\text {th }}$ June, 2015 , Pp. 155-158.

Hodasi, J. K. M. (1984). Some observation on edible giant land snails of West Africa. World Animal Reviews, 52, 24-25.

lbe, S. N. (1998). An introduction to genetics and animal breeding. Ikeja, Nigeria, Longman Nigeria Plc. Pp. 108-139.

Ibom, L. A. (2009). Variations in reproductive and growth performance traits of White-skinned x Black-skinned African giant snail hatchlings [Archachatina marginata (Swainson)] in Obubra, Nigeria. Doctor of Philosophy Thesis, Department of Animal Science, University of Calabar, Calabar, Nigeria. Pp. 166.

Ibom, L. A. and Okon, B. (2012). Evaluation of growth and correlations between body weight and shell measurements of the juveniles of two ectotypes of Archachatina marginata var. saturalis (P) snail. International Journal of Agriculture and Forestry, 2(4), 145-149.

Ibom, L. A., Okon, B., \& Adinya, I. B. (2011). Evaluation of growth and body traits of snailets obtained from the crossbreeding of black skinned and white skinned snail (Archachatina marginata) in the Niger Delta area of Nigeria. African Journal of Agricultural Research. 6(2), 4968-4972.

Ibom, L. A., Okon, B., \& Asuquo, L. E. (2014). Heterosis of body weight and egg weights of $\mathrm{F}_{1}$ snails (Archachatina marginata var. saturalis) in Obubra, Nigeria. Journal of Biology, Agriculture and Healthcare. 4(17), 120-123.

Imran, G. T., \& Alarape, A. A. A. (2012). Assessment of growth and reproduction performance of African giant snail (Archachatina marginata Swainson) under three systems. Proceedings of the $1^{\text {st }}$ International Conference on Giant African Land Snails. Abeokuta, $12^{\text {th }}-15^{\text {th }}$ February, 2012, Pp. 92-94.

Isah, O. A., \& Peter, E. I. (2012). Growth performance and carcass profile of African giant snail (Archachatina marginata) fed unripe paw-paw fruit and concentrate diets of varying protein content. Proceedings of the $1^{\text {st }}$ International Conference on Giant African Land Snails. Abeokuta, $12^{\text {th }}-15^{\text {th }}$ February, 2012, Pp. 152-154.

Jayeola, O. A., Onadeko, S. A., Ademola, K. O., Osunsina, I. O. O., Shotuyo, A. L. A., \& Okeyoyin; O. A. (2013). Preliminary report on growth performance of Archachatina marginata fed Jatropha carcass. Proceedings of the $2^{\text {nd }}$ International Conference/Workshop on Giant African Land Snail (NetGALS), Abeokuta, $2^{\text {nd }}-5^{\text {th }}$ June, 2013. Pp. 110-113.

Nwakpu, P. E., \& Omeje, S. I. (2005). Influence of genotype and weight of gilts on the litter size and litter growth of inbred native $x$ large white pig crosses. Tropical Journal of Animal Science, 8, 1-4.

Obi, I. U. (2002). Statistical methods of detecting difference between treatment means and research methodology issues in laboratory and field experiments. $2^{\text {nd }}$ ed. Express Publication Ltd. Enugu. Pp. 1-21.

Okon, B., \& Ibom, L. A. (2012). Snail Breeding and Snailery Management. Calabar: Freshdew Publication, Pp. 1-90.

Okon, B. Ibom, L. A., Ukorebi, B. A., \& Okon, F. I. (2014). Growth and morphometric traits of Achatina achatina $(\mathrm{L})$ juvenile snails in Calabar, Nigeria. Proceedings of the $3^{\text {rd }}$ Conference/Workshop on giant land snail (NetGALS), Abeokuta, Pp. 15-21.

Okon, B., Ibom, L. A., \& Njume, G. N. (2013). Genetic differentiation between the black-skinned and white-skinned snails (Archachatina marginata) using random amplified polymorphic DNAs. African Journal of Biotechnology, 12(12), 5035-5039.

Okon, B., Ibom, L. A., Etuk, N. E., \& Akpan, E. W. (2008). Variations in growth pattern and conformation of snails. Influence of strain and location on isometry of growth in Cross River State of Nigeria. Journal of Agriculture, Forestry and the Social Sciences, 6(2), 218-227.

Okon, B., Ibom, L. A., Ettah, H. E., \& Udoh, U. H. (2012a). Comparative differentiation of morphormetric traits and body weight prediction of giant African land snails with four whorls in Niger Delta region of Nigeria. Journal of Agricultural Science, 4(10), $205-211$.

Okon, B., Ibom, L. A., Nsa, E. E., \& Ubua, J. A. (2012b). Reproductive and growth traits of parents and $F_{1}$ Hatchlings of Achatina achatina ( $\mathrm{L}$ ) snails under mixed feeding regime with graded levels of swamp taro cocoyam (Cytosperma chamissonis) and paw-paw leaves (Carica papaya). Journal of Agricultural Science. 1(11), 289-298.

Okonkwo, A. C., Isaac, I. J., Nkanga, I., \&Usoro O. O. (2000). Effect of various feeding regimes on the performance of snail (Archachatina marginata). Proceedings of $25^{\text {th }}$ Annual Conference of the Nigerian Society for Animal Production, 19 - 25 March, Umudike. Pp. 314-316.

Olawoyin, O. O., \& Ogogo, A. U. (2006). Prediction of optimum stocking density in growing African giant land snails. Tropical Journal of Animal Science. 9(2), 75-84.

Onuoha, C. A. (2014). Performance of hatchling snails (Archachatina marginata) fed varying dietary levels of kenaf grain meal in the diet. Proceedings of the $3^{\text {rd }}$ International/Workshops on giant African land snail, Abeokuta, $1^{\text {st }}-4^{\text {th }}$ June, 2014, Pp. 56-59.

Omole, A. J. (1998). The utilization of energy supplement on performance characteristics of grower snail (Archachatina marginata) M. Phil. Thesis, University of lbadan (unpublished).

Omole, A. J., Taiwo, A. A., \& Amusan, J. A. (2007). Technical guide/bulletin practical snail farming. Ibadan, Nigeria, Institute of Agricultural Research and Training- Moor Plantation. Pp. 1416.

Oni, O. O., Akanni, K. T., \& Akinnusi, F. A. O. (2012). Sire Strain influence on the reproductive performance of two strains of giant African land snails (GALS) in south western Nigeria. Proceedings $1^{\text {st }}$ International Conference on giant African 
land snails held between $12^{\text {th }}-15^{\text {th }}$ February, 2012 at Federal University of Agriculture, Abeokuta, Ogun State. Pp. 61-65.

Opara, P. N. (2010). Evaluation of growth of $F_{1}$-hybrids of 3 ectotypes of African giant snail (Archachatina marginata). $B$. Agric. Project, Department of Animal Science, Faculty of Agriculture, Forestry and Wildlife Resources Management. University of Calabar, Calabar, Nigeria. Pp. 18-35.

Oyeagu, C. E., Udeh, F. U., Uzochukwu, I. E., Osita, C. O. Ugwu, S. O. C., \& Agugom, O. H. (2015). Growth and reproductive traits of Archachatina marginata snails fed diets containing Centrosema pubscens leaves in Nsukka, Enugu State. Proceedings of the $4^{\text {th }}$ International Conference/Workshop on giant African land snails (NetGALS), Awka, $1^{\text {st }}-4^{\text {th }}$ June, 2015, Pp 7-15.
Oyelade, A. Y. O., Lamidi, A. W., Umoru, J. I., \& Agbaye, F. G. P. (2013). Performance characteristics of giant African land snails (GALS) (Archachatina marginata) fed fresh and air dry water leaf (Talinum traingulare). Proceedings of the $2^{\text {nd }}$ International Conference/Workshop on giant African land snails (NetGALS). Abeokuta, $2^{\text {nd }}-5^{\text {th }}$ June, 2015, Pp. 52-54.

SAS (2006). Statistical analysis system users guide statistical analysis systems institute Inc., Cary, NC, USA.

Udedibie, A. B. I., Onwuene, I. C., Iloeje, M. U., \& Anyanwu, G. (1986). Review of projects on snail farming. Animal Resource, School of Agriculture, Federal University of Technology, Owerri, Pp. 33-36. 